\title{
A Monetary View of the Balance of Payments
}

\author{
DONALD S. KEMP
}

. $\mathrm{N}$ surveying the body of research dealing with the balance of payments, two major shortcomings are immediately apparent. ${ }^{1}$ First, there are no widely accepted theories of the balance of payments which simultaneously incorporate both the current and capital account. The great majority of models used in payments theory consider either the capital account or the current account separately. Second, there have been very few attempts to include even the fundamentals of portfolio choice theory in balance-of-payments models. This is particularly surprising in view of the essentially monetary nature of payments theory.

This article presents an approach to payments theory which addresses both of these shortcomings. Since this essentially involves an extension of the rudiments of monetary theory to the area of the balance of pay. ments, it is henceforth referred to as a monetary view of the balance of payments (MBOP). ${ }^{2}$

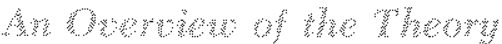

The MBOP may be summarized by the proposition that the transactions recorded in balance-of-payments (BOP) statistics reflect aggregate portfolio decisions by both foreign and domestic economic units. Under

\footnotetext{
1For a lucid analysis of the current state of payments theory, see Anne $O$. Krueger, "Balance-of-Payments Theory," The Journal of Economic Literature (March 1969), pp. 1-26.

2The theoretical foundation of this approach to payments theory may be found in Robert A. Mundel, Monetary Theory: Infation, Interest, and Growth in the World Economy (Paciffe Palisades, California: Goodyear, 1971). The formal model, presented later in this article, draws extensively on work done at the University of Chicago Workshop in International Economics and the analysis presented in Harry G. Johnson, "The Monetary Approach to Balance-of-Payments Theory," Further Essays in Monetary Economics (Cambridge: Harvard University Press, 1973), pp, 229-49. This article is essentially a synthesis and extension of these previous works.
}

a system of fixed exchange rates, such as the gold standard or the type of arrangement set up in 1944 at Bretton Woods, overall net surpluses (deficits) in the trade and capital accounts are viewed as Hows associated with either an excess demand for money on the part of domestic (foreign) economic units or an excess supply of money in foreign economies (the domestic economy). Consequently, in analyzing the rate of change of international reserves (the money account ${ }^{3}$ ) the monetary approach focuses on the de terminants of the excess demand for or supply of money. According to this view, surpluses (deficits) in the money account measure the rate at which money balances are being accumulated (reduced) domestically. That is, a BOP flow is one of the mechanisms by which actual money balances are adjusted to their desired levels.

Suppose, for example, there is an autonomous increase in the money supply of country $j$, which leads to an increase in the demand for goods, services, and securities in that country. Under a system of fixed exchange rates, any such increase in domestic demand will result in a tendency for prices of domestio real and financial assets in country $\mathrm{j}$ to rise, in the short run, relative to those in foreign markets. Economic units in country $\mathrm{j}$ will react by decreasing their demands for domestic real and financial assets in favor of foreign assets while domestic suppliers of these

\footnotetext{
XThe overall net balance in the trade and capital accounts will henceforth be referred to as the money account. This reflects the fact that all transactions recorded below the line in this account have a direct impact on a nation's money supply. Under a pure gold standard, changes in official gold holdings are the only item below the line in this account Under a Bretton Woods type system changes in official holdings of gold, SDRs, and foreign exchange and changes in the reserve position at the IMF are all included below the line in the money account.
} 
assets will seek to sell more at home and less abroad. At the same time, foreign economic units will decrease their demands for the assets of country $j$ and foreign suppliers will attempt to sell more of their own assets in country j. All of these factors work in favor of an increase in imports and a decrease in exports in country $\mathrm{j}$. The resultant deterioration of the BOP reHects the exchange of money balances for real and financial assets by economic units of country $\mathrm{j}$. The foreign recipients of these money balances will convert them into their own currencies at their respective central banks. These foreign central banks will then present the balances to the central bank in country $j$ in return for international reserves. Since international reserves are one of the components of a country's monetary base ${ }^{4}$, the effect of this transaction will be a decrease in the money supply of country $j$ towards its level prior to the autonomous increase and an increase in the money supplies of its surplus trading partners.

Under a system of freely floating exchange rates, the required adjustment of money balances is accomplished through movements in the exchange rate. Under such a system the BOP (on a money account basis) equals zero by definition and there are no intercountry movements of international reserves. As such, required adjustments in money balances cannot be accommodated through balance-of-payments flows. In this case the adjustment of actual money balances to their desired levels is accomplished by changes in domestic prices and exchange rates (which change concomitantly with and accommodate the required movement in domestic price levels).

The above approach is in sharp contrast with what amounts to the current conventional wisdom of payments theory; namely, the elasticities and absorption approaches. Implicit in both of these approaches is the assumption that either there are no monetary consequences associated with the BOP, or that to the extent the potential for such consequences exists, they can be and are absorbed (sterilized) by domestic monetary authorities. ${ }^{\overline{5}}$

\footnotetext{
EFo" a detailed discussion and analysis of the concept of the monetary base, see Leonall C. Andersen and Jerry L. Jordan, "The Monetary Base - Explanation and Analytical Use," this Review (August 1968), pp. 7-11.

The elasticity and absorption approaches are theories of the trade account alone and they neglect the issue of capital flows. For a discussion of the essentials of the elasticities approach, see Joan Robinson, "The Foreign Exchanges," Readings in the Theory of International Trade, Committee of the American Economic Association (Philadelphia; The Blakiston Company, 1949), pp. 83.103. For a discussion of the absorption approach, see Sidney S. Alexander, "Effects of
}

The MBOP regards all BOP deficits and surpluses and movements in floating exchange rates as phases in a stock adjustment which are the result of a disparity between the demand for and supply of money, This approach asserts that, under a system of fixed exchange rates, there are inflows (outflows) of international reserves associated with BOP surpluses (deficits) and that these flows cannot be sterilized in the long run. Furthermore, because of the impact of these reserve flows on a country's monetary base, they will result in variations in the supply of money relative to the demand for it and thus have an equilibrating impact on the level of money balances and the BOP. According to this view, the only way to obtain persistent deficits or surpluses is to construct a model in which the need for stock adjustments is being continuously recreated.

The only solutions to these reserve flows are processes which facilitate the return of actual money balances to their desired levels. This adjustment can be accomplished either automatically, through inflows or outflows of international reserves, or through appropriate actions by the domestic monetary authorities which change some other component of the monetary base by the same amount. Under a system of freely floating exchange rates the adjustment is also accomplished either automatically by changes in domestic price levels and the concomitant changes in the exchange rate, or again by the appropriate actions on the part of the monetary authorities. The only other potentially successful policy actions available are those which, in the end, have the same effect on money balances as those just mentioned.

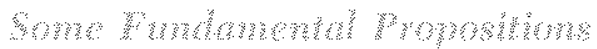

In order to facilitate the development of a model later in this article, there are some fundamental propositions associated with the MBOP that should be discussed.

1) The MBOP maintains that the transactions recorded in the balance of payments are essentially a reflection of monetary phenomena. As such, it places emphasis on the direct influence of an excess demand for or supply of money on the BOP.

Implicit in this approach is the assumption that the demand for and supply of money are stable functions

a Devaluation on a Trade Balance," Readings in International Economics, Committee of the American Economic Association (Homewood, Illinois: Richard D. Irwin, Inc., 1968) pp, 35973. For a discussion of the differences between the monetarists" approach and both the elasticities and absorption approaches to payments theory, see Johnson, "The Monetary Approach to Balance-of-Payments Theory, ${ }^{x}$ pp, 229-49. 
of a limited number of variables. The MBOP does not imply that changes in the money supply are the only factors which affeet the BOP. It nevertheless does say that the primary channel by which changes in any real variable affect the $\mathrm{BOP}$ is through their effects on the demand for or supply of money. ${ }^{6}$ Thus, any analysis of the impact of a policy or other change must begin with an analysis of how this change generates a divergence between actual and desired money balances or affects such a divergence that already exists.

2) In the analysis presented in this article, the crucial $B O P$ concept is that which captures all transactions reflecting the adjustment of actual money balances to their desired levels. That is, the only transactions considered below the line are those which have an influence on domestic and foreign monetary bases and thus on domestic and foreign money supplies. $^{7}$

The analysis presented here does not attempt to provide a theory of the individual subaccounts; it merely lumps the individual components (goods, services, transfers, short- and long-term capital) into a single category - "items above the line." This approach recognizes that an excess supply of or demand for money may be cleared through the markets for either goods, services, or securities. ${ }^{8}$ Furthermore, if the $B O P$ is viewed within this framework, the pitfalls of placing emphasis on any particular subaccount are obvious. For example, the effects on aggregate economic activity of a deficit in the merchandise trade account could be neutralized by a surplus in one of the capital accounts. In this case, any negative aggregate demand effects resulting from an increase in imports of goods would be offset by an inflow of capital and thus an increase in investment demand. The two ef-

FFor an analysis of the $\mathrm{BOP}$ effects of changes in a real variable (a change in tariff) within a monetarist's framework, see Michael Mussa, "A Monetary Approach to Balance-of Payments Analysis," Journal of Money, Credit and Banking (August 1974), pp. 333-51.

iFor a review of balance-of-payments concepts and their meaning, see John Pippenger, "Balance-of-Payments Def. cits: Measurement and interpretation," this Review (November 1973), pp. 6-14. For a discussion of which transactions to include below the line, see footnote 3 of this anticle.

s'This is not to say the MBOP framework wonld not ho tseful in analyzing individual subaccounts. However, such analysis would recquire a rigorous specification of the channels of monetary inflence. For a survey and analysis of the literature pertaining to these chamels, see Roger W. Spencer, "Channels of Monetary Infuence: A Survey," this Review (November 1974), pp. 8-26. For an example of how this framework could be applied to the analysis of the capital account alone, see Pentti J. K. Kouri and Michael G. Porter, "International Capital Flows and Portfolio Equilibrium," Jottrnal of Political Economy (May/June 1974), pp. 443-67. fects would offset each other and aggregate money balances would be unchanged.

3) The MBOP relies on the assumption of an efficient world market for goods, services, and securities. ${ }^{9}$ Under a system of fixed exchange rates, the price of any good or service in one country relative to its price in any other country can change only in the short run. Likewise, the rate of return on any asset can differ from the rate of return on assets of comparable risk and maturity in any other country only in the short run. It follows that in the long run price levels and interest rates in all countries must move rigidly in line with one another. In fact, in a fixed exchange rate regime it is the attempts to arbitrage intercountry price and interest rate differentials that are the driving force leading to the reduction or accumulation of money balances and a concomitant temporary BOP deficit or surplus.

Under a system of freely floating exchange rates, price levels may move at different rates between countries. However, the impact of these differential rates of change on individual relative prices between countries is offset by opposite movements in exchange rates. The same arbitrage opportunities that lead to reserve flows under fixed rates lead to exchange rate adjustments that exactly compensate for differential price level changes between countries.

4) The MBOP is a theory of an automatic adjustment process. According to this theory, any BOP disequilibrium or exchange rate movement reflects a disparity between actual and desired money balances and will automatically correct itself. While the adjustment process is different under different exchange rate regimes, the implication is that the process is automatic and that its effects camnot be neutralized in the long run. Any BOP imbalance or exchange rate change is a phase in the automatic adjustment process and attempts to counter these processes merely increase the forces which give rise to the adjustment ultimately required for a retum to equilibrium.

5) The MBOP is concerned primarily with the long rum. The approach recognizes that short-rum analysis is often complicated by the fact that the postulated adjustment behavior is incomplete in the short run. For example, the adjustment of actual

\footnotetext{
While it is acknowledged that there are some goods that are not traded interaationally, there are limits to relative price changes between these non-traded goods and other (traded) goods. The nigher the elasticities of substitution between these two classes of goods in both production and consumption, the smaller the scope for relative price changes and the more direct the international price interdependence.
} 
money balances to their desired levels does not occur instantaneously, but rather requires the passage of time. As another example, it is possible that the monetary authorities may attempt to neutralize the impact of international reserve flows on their respective money supplies in the short run. ${ }^{10}$ However, the MBOP asserts that governments camnot follow such policies in the long run. This seems reasonable because, in the long run, success in neutralizing the effects of international reserve flows implies that the governments of some (surplus) countries are willing to trade investment and consumption goods for foreign currency balances. The accumulation of these balances by surplus country goveriments represents a nonmarket induced transfer of wealth away from domestic to foreign consumers. For whatever reason, it is unrealistic to suppose that a government would pursue such policies in the long run.

6) An implication of this theory is that, under a system of fixed exchange rates, domestic monetary policy does not control a country's money supply. Excessive monetary expansion (contraction), via expansion (contraction) of some controllable component of the monetary base, will result in an outflow (inflow) of international reserves (an uncontrollable component of the monetary base) and a tendency for the money supply to return to its former level. ${ }^{11}$ The resulting BOP deficit (surplus) is only a reflection of these uncontrollable international reserve outflows (inHows). Through this process, the inflationary or deflationary impact of domestic monetary policy is mitigated with respect to the domestic economy and is imposed on the rest of the world via inter-country Hows of international reserves. At the same time, however, the domestic economy is subject to the influence of inflationary or deflationary monetary actions taken in other countries.

Under a system of freely floating exchange rates, the domestic monetary authorities retain dominant control over the money supply, while the interaction of domestic and foreign monetary policies determines the exchange rate rather than the BOP (which is now zero by definition). In this case, a country neither imports nor exports international reserves. As a result, the domestic economy is subjected to the full consequences of inflationary or deflationary domestic

10 For an analysis of West German attempts to neutralize the effects of reserve flows, see Manfred Willms, "Controlling Money in an Open Economy: The German Case," this Review (April 1971), pp. 10-27.

11While this is true for most countries, it is not necessarily the case for a reserve currency country. The special case of a reserve currency country will be discussed in the next section. monetary policies and is insulated from the effects of monetary actions taken in other countries.

7) Another feature of the MBOP is that it provides a framework within which one is able to assess the differential impact of monetary disturbances which occur in a world in which there is at least one reserve currency country (RCC) as opposed to those occurring in a world with no RCCs. An RCC is a country whose currency is held by others as a form of international reserves. It is this special status afforded to the currency of the RCC which leads to a slightly altered adjustment process for the world and the RCC itself.

\section{The Spenth Che of a heremen \\ Curmor combl}

Because international reserves and reserve currencies exist only under a system of fixed exchange rates, the following analysis applies only to that case. For all non-RCCs, expansionary (contractionary) monetary policies are offset by a BOP deficit (surplus) and the resulting contraction (expansion) of the international reserve component of the monetary base. However, for an RCC this need not be the case. An expansionary (contractionary) monetary policy in the RCC may have no effect on its BOP as defined in this article. However, the RCC's trading partners will alm ways experience a BOP surplus (deficit) and an inflow (outtlow) of intemational reserves as a result of such RCC policies. ${ }^{12}$ The reason for this is that the $\mathrm{RCC}$ currency is held by foreign central banks as a form of international reserves. While non-RCC monetary authorities are not willing to accumulate large balanc?s denominated in other non-RCC currencies, they are willing to accumulate large balances denominated in the RCC currency. Because these balances are themselves a type of international reserves, non-RCC monetary authorities may not be inclined to present them to the RCC authorities in exchange for other international reserves.

However, to the extent that the RCC loses no international reserves as a result of an increase in other components of its monetary base, it does experience an accumulation of liquid liabilities to foreign official holders. ${ }^{13}$ As these liabilities of the RCC are re-

12Recall that the BOP concept used in this article is the balance in the money account. That is, the only items recorded below the line are those that affect the domestic money supply.

13. While the accumulations or reductions of the holdings of liabilities do not affect the RCC balance of payments as defined in this article, they do affect some RCC balance-of- 
garded as assets by foreign official holders, their accumulation represents an inflow of international reserves and a BOP surplus for RCC trading partners.

The how and why of all of this can be brought out by reference to the balance sheets of the world's monetary authorities. While the following analysis applies to the case of expansionary monetary policy in the $\mathrm{RCC}$, it is equally applicable to the analysis of contractionary monetary policy. In addition, in order to simplify the analysis we will assume that foreign central banks invest all of their RCC currency holdings in government securities issued by the RCC. However, we fully recognize that this need not be the case. Non-RCC central banks can and frequently do invest their RCC currency holdings in other assets or simply allow them to accumulate as deposits at the RCC central bank. Whatever the non-RCC authorities decide to do, however, all that is crucial for our analysis to hold is that they do not accumulate deposits at the RCC central bank.

Illustration I indicates what happens to the monetary bases of all countries as a result of an attempt by the RCC monetary authorities to increase the domestic money supply in the face of a fixed demand for money. Tier (A) illustrates that the initial impact of such an undertaking is to increase the monetary base of the RCC only. Tier (B) illustrates what happens to the respective monetary bases as a result of the fortheoming intercountry reserve flows. Non-RCCs accumulate international reserves $(R)$ in the form of deposits denominated in the RCC currency held at the RCC central bank. As long as these $\mathrm{R}$ are held in this form, the RCC monetary base decreases towards its initial level and the non-RCC monetary bases increase, just as in the case of a world in which there are no RCCs.

Since the non-RCCs view these reserve currency balances as $R$, they are willing to accumulate them in the same manner that they accumulate other $R$. However, these $\mathbf{R}$ differ from others in one significant aspect - namely, they can be invested in government securities issued by the RCC. When non-RCCs choose to do this, the effects are as illustrated in tier (C). When non-RCC monetary authorities purchase RCC government securities, the OL entry in the RCC balance sheet is drawn down. This has the effect of increasing the monetary base of the RCC without causing a decrease in the monetary bases of the non-RCCs.

payments concepts. For example, such transactions would affect the Official Settlements Balance in the United States.

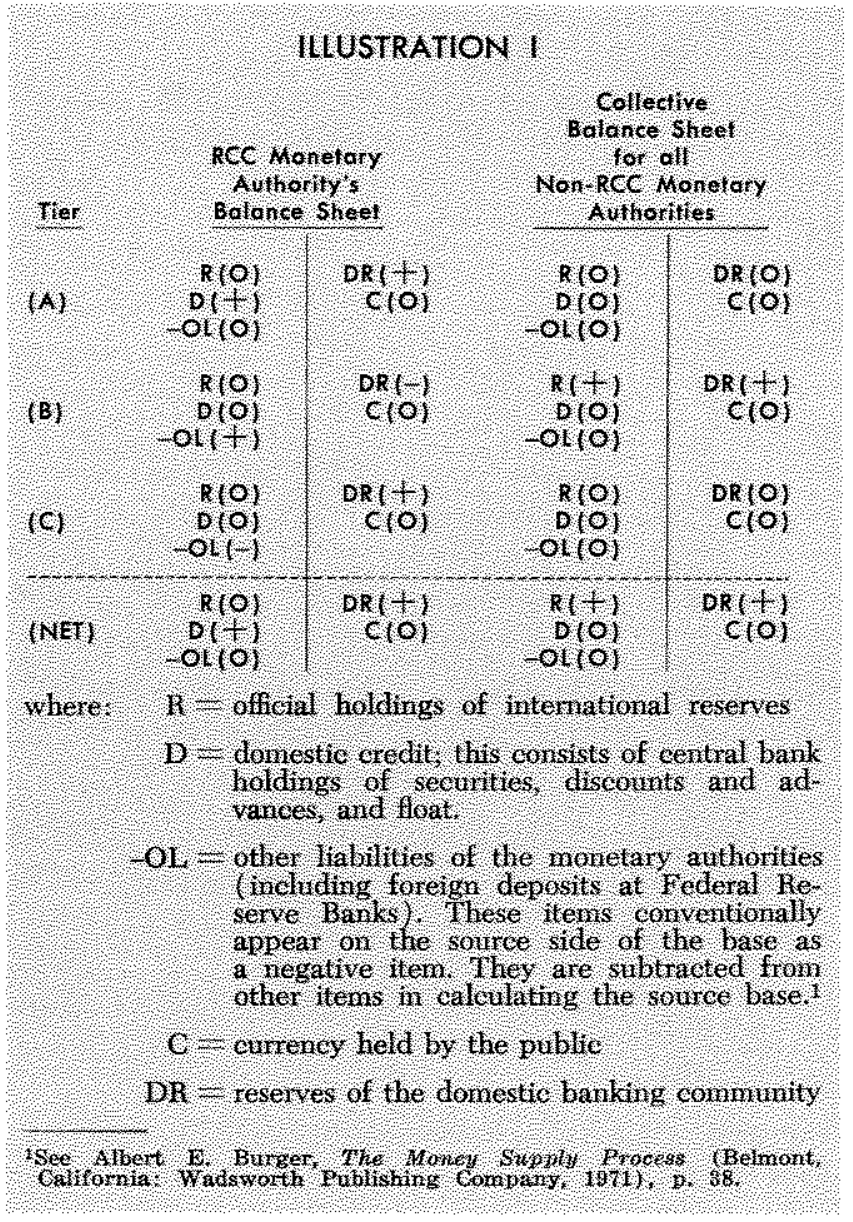

The net effect of all of this is that the monetary bases of all countries have increased (as shown in the NET tier).

In view of the above analysis, a world in which there exists at least one RCC differs significantly from a world in which there are no RCCs. In a world with RCCs, BOP deficits and surpluses may by themselves decrease and increase the level of $R$ in the world and in individual countries. In a world with no RCCs, BOP deficits and surpluses result in a redistribution of an existing stock of $\mathrm{R}$ among countries, but produce no change in the overall level. As a result, in a world with RCCs, the world and each individual non-RCC will ordinarily experience much more difficulty in controlling its money supply. Thus, the existence of RCCs compounds the problems of money stock control which are already inherent in any system of fixed exchange rates.

In addition, this analysis implies that the inflationary or deflationary impact of RCC monetary policy is spread over the entire world. Unlike the case of a non-RCC, however, there may be no mitigation of the 
impact on the domestic economy since the RCC may neither gain nor lose reserves. As a result, prices in the RCC could change by the same amount as they would under a system of freely floating exchange rates. What's worse, however, is that the rest of the world will gain or lose international reserves and bear the same price level impact as the RCC. 'Thus, the potential for large BOP surpluses and deficits and for world wide inflations and deflations are greater under a fixed exchange rate system with RCCs than under any other system considered in this article.

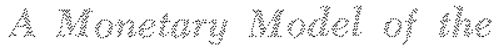

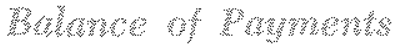

Now that the essential features of the MBOP have been spelled out let us tum to the derivation of a model in which these features are expressed by a set of equations, ${ }^{14}$ First, the model is derived for a nonRCC under a system of fixed exchange rates. Second, the same model is applied to the case of an RCC under fixed exchange rates. Finally, the model is applied to the case of freely floating exchange rates.

The common elements in each of these models are stable money demand and money supply functions. ${ }^{15}$ The money supply function for each country may be stated as

(1) $\mathrm{MS}_{1}=\mathrm{a}_{1}\left[\mathrm{R}_{1}+\mathrm{D}_{1}\right]$

where: $\mathrm{MS}_{j}=$ money supply in country $\mathrm{j}$

$a_{j}=$ money multiplier in country $j$

$\mathbf{R}_{j}=$ official holdings of international reserves in country i; hereafter referred to as the intemational component of the monetary base.

$\mathrm{D}_{1}=$ all other components of the monetary base in country $j$; hereafter referred to as the domestically controlled component of the monetary base.

$\mathrm{D}_{1}+\mathrm{R}_{1}=\mathrm{MB}_{3}=$ monetary base in country $\mathrm{j}$

The demand for money in each country is assumed to be a function of real income, the nominal rate of interest, and prices.

(2) $\mathrm{MD}_{1}=\mathbf{f}_{1}\left[\mathrm{y}_{3}, \mathbf{r}, \mathrm{P}\right]$

where: $\mathrm{MD}_{3}=$ demand for money in country $\mathrm{j}$

$P=$ price index in the world and thus in

14 In order to simplify the presentation, many of the steps in the derivation of the model have been bypassed in the text. For the interested reader, a more thorough presentation of the model is provided in an appendix, which is available from this Bank upon request.

${ }^{15}$ For an analysis of the development of the money supoly function employed in this article, see Jerry $L_{\text {i. }}$ Jordan, "Elements of Motey Stock Determination," this Review (October 1969), pp, 10-19.

${ }^{16}$ This reflects the assumption that under a system of fixed exchange rates, a country's price level and interest rates

$$
\begin{aligned}
y_{1} & =\text { real income in country } j \\
r & =\text { nominal rate of interest in the world and } \\
& \text { thus in country } j .
\end{aligned}
$$

In accordance with the general monetarist framework of the model, country $j$ is in equilibrium if and only if the growth of the supply of money equals the growth of the demand for money. We are able to specify the conditions necessary for fulfilling this requirement by expressing equations (1) and (2) in terms of rates of change and then equating the resulting expressions. This procedure allows us to derive an expression for the rate of growth of international reserves in country $\mathrm{j} .{ }^{17}$

$$
\begin{aligned}
& \text { (3) } \frac{\mathbf{R}_{j}}{M B_{1}} g_{k_{j}}=g_{p}+\alpha_{j} g_{y_{j}}+\beta_{j} g_{r}-\frac{D_{1}}{M_{1}} g_{s_{j}} \\
& \text { where: } a_{1}=\text { income elasticity of demand for money in } \\
& \beta_{1}=\underset{\text { interest rate elasticity of demand for money }}{\text { in country } i \text {. }}
\end{aligned}
$$

We are able to derive an expression for the growth rate of world prices $\left[\mathrm{g}_{\mathrm{p}}\right]$ by summing the expressions for the growth rates of the demand for and supply of money over all countries and equating the resultant expressions.

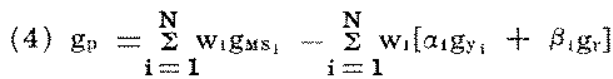

$$
\begin{aligned}
& \text { where: } w_{i}=\frac{M S_{i}}{\sum_{\mathrm{xs}_{i}}}=\begin{array}{l}
\text { weights calculated on the basis of } \\
\begin{array}{l}
\text { money supplies converted by ex- } \\
\text { change rates to equivalent units of } \\
\text { currency } i .
\end{array}
\end{array}
\end{aligned}
$$

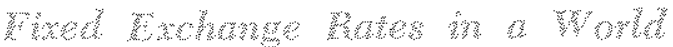

\section{whing wark}

Recall that by definition $g_{R_{j}}=\frac{1}{R_{j}} \frac{d R_{j}}{d t}$. Under a system of fixed exchange rates in a world in which there are no reserve currency countries, $\frac{\mathrm{dR}_{\mathrm{i}}}{\mathrm{dt}}$ is the expression for the balance of payments in the money account. It represents the rate at which country $j$ is either gaining or losing international reserves during a given time period $(t)$. With this in mind, and upon making some simplifying assumptions regarding the interest and income elasticities of demand for money,

move in line with the world price level and interest rates. However, in the case of freely floating exchange rates the assumption regarding the price level is no longer valid. As such, the money demand function must be specified somewhat differently in that case.

${ }^{17}$ Henceforth in this article $g_{x}=\frac{d \ln x}{d t}$. That is, $g_{x}$ is the expression for the continuous rate of growth of variable $x$. 
we are able to substitute expression (4) into expression (3) and get an expression for the balance of payments in country j. ${ }^{18}$

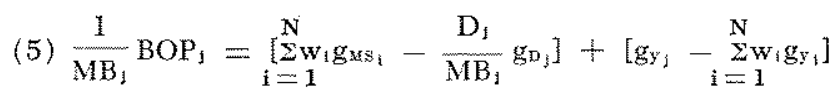

Expression (5) is essentially an embodiment of the features of the price specie flow mechanism, which operates under a system of fixed exchange rates in a world in which there are no reserve currency countries. ${ }^{19}$ That is, expression (5) states that the BOP is a function of:

1) the rate of growth of real income in country $j$ relative to the average rate of growth of real income for all countries, and

2) the rate of growth of the domestically controlled component of the monetary base in country i relative to an average rate of money growth for the whole world.

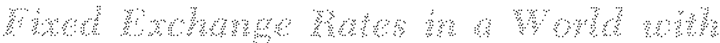

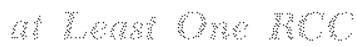

In a world in which there is at least one $\mathrm{RCC}$, expression (5) is still an appropriate representation of the forces giving rise to BOP flows in non-RCCs. However, for an RCC there may be no international reserve flows associated with the BOP accounts; in which case $\mathrm{g}_{\mathrm{R}_{j}}=0$. In the case of an $\mathrm{RCC}$, excessive expansion (contraction) of the domestically controlled component of the monetary base need not lead to an offsetting contraction (expansion) of the international reserve component. At the same time, however, excessive expansion (contraction) of the domestically controlled component of the monetary base

1.8 We have assumed that $\alpha_{i}=1$ for all $i$ and that $\beta_{j} \underset{i=1}{=}=w_{1} \beta_{i}$, Neither of these assumptions are cncial to the analysis at hand. They are invoked here mainly to simplify the presentation. The assumption that $\alpha_{\xi}=1$ is interpreted as assuming that the income elasticity of demand for money is unity in all countries. Assuming that $\sum_{1}^{N} w_{1} \beta_{1}=\beta_{3}$ means that the interest elasticity of demand for money in country $j$ is equal to a weighted average of the interest elasticities of demand for money in all comtries. A more restrictive implication of this assumption would be that the interest elasticities are equal in all countries.

19The price specie flow mechanism is an attempt to explain international gold flows under the gold standare. It is associated primarily with the work of David flume in the 18 th century, However, in our case the BOP includes more than just gold flows. it includes flows of all international reserves - gold, SDRs, foreign exchange, and reserve positions at the MMr. in the RCC will lead to an accumulation (reduction) of international reserves in all other countries. As mentioned previously, we will assume that these intemational reserves will be held in the form of securities issued by the RCC government to non-RCC official holders. For the RCC, it is the net accumulation or reduction of such liabilities that is determined by monetary actions in our model. This process can be captured in our model by setting $\mathrm{g}_{\mathrm{s}} \mathrm{x}=0$ (where the RCC is the $\mathrm{j}^{\text {th }}$ country) and $\mathrm{N}$

replacing the term $\Sigma w_{i s s}$ in expression (5) with $i=1$

a more detailed formulation of the factors contributing to the growth of the money supply in all countries.

$$
\begin{aligned}
& \text { (6) } \frac{1}{\mathrm{MB}_{\mathrm{w}}} \mathrm{BOL}_{\mathrm{BCO}}=\left[\sum_{\mathrm{i}=1}^{\mathrm{N}} \mathrm{w}_{4} \frac{\mathrm{D}_{\mathrm{t}}}{\mathrm{MB}_{1}} \mathrm{~g}_{\mathrm{i}_{4}}-\frac{\mathrm{D}_{\mathrm{RCe}}}{\mathrm{MB}_{\mathrm{Rec}}} \mathrm{g}_{\mathrm{D}_{\mathrm{BOC}}}\right] \\
& +\left[g_{y_{\mathrm{R}, C O}}-\sum_{i=1}^{N} w_{1} g_{y_{1}}\right]
\end{aligned}
$$

where: $\quad M B_{\mathrm{w}}=$ the sum of the monetary bases of all countries in the world.

BOL $_{\text {reo }}=$ the net accumulation of claims against the RCC by foreign official institutions during time period $(t), 20$

This expression states that the change in the level of the liabilities of the RCC to foreign official holders that results from domestic monetary policy in the $\mathrm{RCC}$ is determined by the following:

1) the rate of growth of the domestically controlled component of the monetary base in the RCC relative to a weighted average of its rate of growth in all countries.

2) the rate of growth of real income in the RCC relative to a weighted average of the rates of growth of real income in all countries.

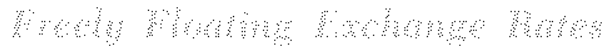

For the case of freely floating exchange rates, two modifications of the model are necessary. First, the model must be adapted to reflect the fact that there are no international reserve flows, so that the growth rate of a country's money supply is determined solely by domestic monetary policy $\left[g_{D_{j}}\right]$. Second, the money demand function must be modified to reflect the fact that the rate of price level change in one country may differ from the rate prevailing in the rest of the world.

\footnotetext{
20For the United States this BOP concept closely resembles the balance on liabilities to foreign official holders. However this account is distinctly different from the BOP concept utilized in equation (5). Equation (5) explains the balance in the money account, whereas the $B O P$ concept used in equation (6) has no relation to the money supply.
} 
Upon incorporating both of these modifications into the model, we are able to derive an expression for the determination of movements in the exchange rate.

(7) $\mathrm{g}_{\mathrm{E}_{j}}=\left[\mathrm{gMs}_{\mathrm{MOW}}-\mathrm{g}_{\mathrm{MS}_{1}}\right]+\left[\mathrm{g}_{\mathrm{y}_{j}}-\mathrm{g}_{\mathrm{HOW}_{\mathrm{HW}}}\right]$

Where: $\quad E_{1}=\frac{P_{\mathrm{Baw}}}{P_{!}}=\begin{aligned} & \text { the price of currency } \mathrm{j} \text { in terms of } \\ & \text { foreign currencies }\end{aligned}$ $P_{\text {tow }}={ }_{i=1}^{\mathrm{N}-1} h_{3} \mathrm{P}_{1}=\begin{aligned} & \text { the price level in the rest of the } \\ & \text { world; that is, a weighted average }\end{aligned}$ of the price levels in all other countries.

$\mathrm{h}_{1}=\frac{\mathrm{y}_{1}}{\mathrm{~N} \frac{1}{\Sigma_{\mathrm{y}_{1}}}}=\underset{\text { weights calculated on the basis of }}{\text { real } G \mathrm{ND}^{2}}$

$P_{f} \ldots$ price level in country $j$

This expression states that the exchange value of currency $j$ in terms of foreign currencies is determined by the rate of growth of the money supply and real income in country $j$ relative to the rate of growth of the money supply and real income respectively in the rest of the world. As such, it implies that currency depreciations are the result of excessive monem tary growth. It therefore supports the proposition that inflation causes depreciation of the domestic currency rather than vice versa.

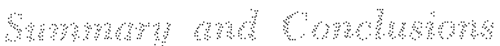

The MBOP may be summarized by the proposition that the transactions recorded in balance-of-payments statistics reflect aggregate portfolio decisions by both foreign and domestic economic units. The framework presented in this article suggests some important policy considerations that cannot be addressed within the framework which characterizes most of the currently accepted body of payments theory.

The analysis presented here casts the balance of payments in the role of an automatic adjustment mechanism. Balance-of-payments deficits and surpluses, or movements in freely floating exchange rates, are viewed as being simultaneously both the result of a divergence between actual and desired money balances and a mechanism by which such a divergence is corrected. As such, persistent balance of payments deficits (surpluses) or depreciations (appreciations) of the foreign exchange value of a currency reflect a continual re-creation of a situation in which excessive monetary expansion in the country in question is greater (less) than the worldwide average. Furthermore, the only solution to such international disturbances are policies which facilitate the equalization of actual and desired money balances.
The futility of tariff and non-tariff barriers to trade which attempt to alter balance-of-payments flows or exchange rate movements becomes readily apparent when one views them within the framework presented above. Suppose, for example, that an import tariff is imposed with the aim of reducing a balance-of-payments deficit in the money account. According to the MBOP, international reserve flows will assure that the balance-of-payments deficit disappears in the long run whether the tariff is imposed or not. That is, even if the tariff were not imposed, the excess money balances, and therefore the deficit, would disappear as a result of the outflow of international reserves. However, if the tariff is imposed, relative prices will be artificially altered from the levels consistent with the most efficient allocation of resources and maximum gains from trade. Furthermore, the situation is no better if the tariff is imposed in retaliation against restrictive trade practices on the part of other nations. In this case, all that the tariff accomplishes is to further distort relative prices and further reduce the welfare of all nations.

Another advantage of the MBOP is that it enables one to clearly evaluate the relative desirability of different exchange rate regimes in terms of their promotion of autonomy of domestic monetary policy and domestic as well as worldwide price stability. Under a system of freely floating exchange rates a country retains dominant control over its money growth, incurs the full consequences of its domestic monetary policy, and is not subject to the effects of inflationary or deflationary monetary policies undertaken in other countries. Under a system of fixed exchange rates in a world in which there are no reserve currency countries, a country loses control of its rate of money growth, has the domestic impact of its monetary policy mitigated, and is subject to the effects of monetary policies pursued by other countries. Under a system of fixed exchange rates in a world in which there is at least one reserve currency country, we have the potential for the worst of botli of the above systems. While the impact of expansionary (contractionary) monetary policies in the reserve currency country is imposed on the rest of the world, there may be no mitigation of their domestic impact. As a result, the entire world is prone towards large changes in its money supply which are initiated by actions taken in the reserve currency country. This conclusion appears to be consistent with the inflationary experiences of the western world which began in the late 1960s.

Finally, if the balance of payments is viewed within the MBOP framework, the pitfalls of placing emphasis 
on any particular BOP subaccount are obvious, A deficit (surplus) in any one account need not have any effect on domestic aggregate economic activity if its impact on money balances is offset by a surplus (deficit) in another account.

This point is especially significant in view of the large merchandise trade deficits that many oil consuming countries have been experiencing. The analysis presented in this article indicates that the im pact of these deficits on money balances, and there fore on aggregate economic activity in the deficit countries, will be substantially reduced as a result of large inflows of capital from OPEC members. Of course this does not mean that oil consuming countries are no worse off now than they were prior to the fourfold increase in oil prices. The MBOP merely states that the impact on GNP will be mitigated through subsequent inflows of capital. The distribution of a given GNP between the residents of oil consuming and oil producing countries however, is altered in favor of the oil producers.

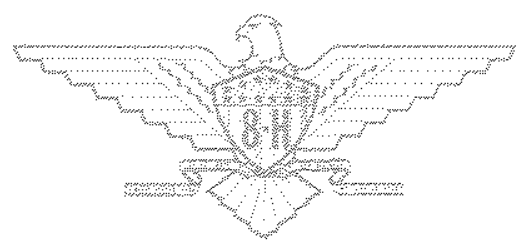

